\title{
THE EFFECT OF PARENTS OF THE PARENTS AND THE POSITION OF CHILDREN WITH FAMILY STRENGTHS ON SELF-ASSISTANCE OF TK CHILDREN IN THE GROUP OF BANGKARI KELOMPOK B PALANGKA RAYA
}

\author{
${ }^{1}$ Seli Charmila. R, ${ }^{2}$ Erny Wahdini, ${ }^{3}$ Ahmad Suriansyah \\ 'Department of in Early Childhood Education, Universitas Lambung Mangkurat, Banjarmasin and 70123 Indonesia \\ ${ }^{2}$ Department of in Education Management, Universitas Lambung Mangkurat, Banjarmasin and 70I23, Indonesia \\ ${ }^{3}$ Department of in Early Childhood Education, Universitas Lambung Mangkurat, Banjarmasin and 70123 Indonesia
}

\begin{tabular}{|c|c|}
\hline ARTICLE INFO & A B STRACT \\
\hline \multirow[t]{2}{*}{$\begin{array}{l}\text { Article history } \\
\text { Received :June } \\
\text { Revised : August } \\
\text { Accepted : September } \\
\text { Keywords: } \\
\text { Parenting, Child's Position, } \\
\text { Family Adherence, Child Inde- } \\
\text { pendence }\end{array}$} & $\begin{array}{l}\text { The aim of the study was to determine the effect of parenting and child position } \\
\text { on family attachment to the independence of children in the Palangka Raya sun } \\
\text { group TK B group Jekan Raya sub-district, Palangka Raya city. The approach of } \\
\text { this research uses quantitative with explanatory method, namely causation. The } \\
\text { population of this study amounted to II8 with proportional sampling techniques } \\
\text { with a sample of } 92 \text { people. The research instrument used a questionnaire, data } \\
\text { analysis using regression analysis and path analysis. The results showed that path } \\
\text { analysis showed that the results of the level of contribution from the path analysis } \\
\text { from the direct relationship of parenting through family attachment to } \\
\text { independence was found to be the level of the indirect relationship is } 0.247 \mathrm{x} \\
0.928=0.229 \text {, the indirect relationship is a positive indirect relationship of } \\
\text { parenting old through family attachment to independence is } 0.229 \text {. This means } \\
\text { that there is an indirect relationship between parenting through family attachment } \\
\text { to independence in the Palangka Raya sun group TK B group, Jekan Raya sub- } \\
\text { district, Palangka Raya city. The results of } \mathrm{r} \text { square analysis show that } 0.875= \\
87.5 \% \text { gives the effect of family attachment to children's independence. The } \\
\text { results of the path analysis from the direct relationship of parenting through } \\
\text { family attachment to independence with Standardized Coefficients beta amounted } \\
\text { to } 0.304 \text { and } 0.929 \text {, it can be seen the level of indirect relationship is } 0.304 \mathrm{x} \\
0.929=0.229 \text { then the indirect relationship is a positive indirect relationship } \\
\text { pattern Parental care through family attachment to independence is } 0.229 \text {. The } \\
\text { results of r square analysis show that 0.886 = 88.6\% gives the influence of the } \\
\text { position of the child through family attachment to the independence of the child. }\end{array}$ \\
\hline & $\begin{array}{l}\text { (c) (i) (2) } \begin{array}{l}\text { C2019 The Authors. Journal of K6, Education, and Management (j- } \\
\text { K6EM). ISSN: 2580-2135. Published by Graduated Program of } \\
\text { Educational Management, Universitas Lambung Mangkurat, }\end{array} \\
\text { Banjarmasin, Indonesia. This is an open access article under the open journal systems. }\end{array}$ \\
\hline
\end{tabular}

*Author correspondence: Seli Charmila. R; E-mail: charmilaseli1@gmail.com 


\section{Introduction}

Family is the first place children learn about moral basics, parents are very responsible about cultivating moral education in children from an early age. Like promiscuity, drugs, robberies and so on today it is very easy to get a child who is in crisis about moral values that are not in accordance with the rules that apply in Indonesia. One of the causes of moral deviation in children is that children behave or Doing negative things is that with the advancement of information technology that is easily accessible to children, children are given the freedom to access the internet early to obtain information that is not accompanied by parental guidance which is one of the wrong parenting styles.

Children who are given the opportunity by their parents to develop independence, their future will be more positive because children are given the opportunity to channel their confidence in positive things. Children who have achievements in the field of education or others are self-enlightening children that children are independent and no longer depend on parents or other people. In children who have independence or low selfconfidence will affect the child's own personality. The level of development of children's independence is different seen from the parenting applied by parents in the family.

Primary education for children is a family where the family is a place where children learn about self-confidence, which is a very important education for children before children enter formal school institutions. Early education for children is from within the family before children enter formal education. The development of the required children's character is seen from the level of family influence that can make them understand the child (Maimunah, 2018).

When children have entered formal institutions such as schools, families still provide education that their children cannot get from school because the family is more in the family environment so that the child is more optimal. In the family environment the child is expected to have a pleasant atmosphere so that the child feels comfortable for the place to study. Child's success in education is one of the factors caused by the existence of a good relationship between children and parents. Parents for children are the first teachers to teach about independence. In families the child can see and learn how to behave well and which are not good. So parents must set a good example to children, become models that can be imitated.

According to Hasan (2009: 26) the type of parenting becomes three, namely the type of authoritative or democratic parenting, authoritarian parenting type, patient type, and type of parenting. There are three types of parenting that we know in society. That is permissive parenting, democratic parenting, and authoritarian parenting. Permissive fostering patterns, namely parenting practices that apply freedom. In this upbringing the child has the right to determine what he will do and parents provide facilities according to the wishes of the child. Democratic upbringing, namely parenting that implements democratic values in the family. Children are respected by their parents, and parents apply rules that children adhere to as long as they do not burden children. Whereas authoritarian parenting, namely parenting that confirms the power of parents in educating their children. Parents apply strict regulations with sanctions, and children must obey. In this upbringing, children are not given the opportunity to obtain their rights. Each parenting style applied by parents has advantages and disadvantages. It all depends on the culture, tradition, and community environment that exists. Parenting is certainly very influential on the behavior of children, both at school, at home, and in society. Children are the gift of the Almighty God, parents who are given the opportunity to care for and educate children so that they can be well guarded, educated with the prevailing norms so that someday children will become useful people for their families and nations. The understanding students needs the ability of schools to learn so they can achieve good learning outcomes.

At the age of the child, the development must be paid more attention to, where the child during this time the child needs guidance. Children are very unique and unique creatures, they have a different level of development with each other at each level. The UUD No. 4 of 1979 concerning child welfare says children basically have the right to be fulfilled by their families, namely their parents, where those rights include: rights to welfare, protection, care and guidance.

Parents should not be negligent in guiding, nurturing and educating children because during the period of development and growth the child is in dire need of attention from his parents (Rahmawati, 2019). As parents many things will be done so that children can achieve their development and growth in childhood by finding out from various information so that parents' knowledge to educate their children is better. Teach children in matters of independence for children responsible for their decisions so that children can better know the needs and interests that are free in themselves.

Family and environment support children in developing their independence so that they are formed in independent personal children in those individuals who have been able to account for decisions that children have taken Novitawati dan Mutiarany (2016). In individuals who are still dependent on the environment or the closest person, especially parents, the child will be difficult to make decisions, the child will be hesitant and afraid of the choices that are still taken not to be able to be responsible for the decisions taken. Providing continuous opportunities for children to develop is one way for children to be independent, believing that they do what children want to do Noorhafizah dan Dahlina (2016). Provide training from simple things that are in accordance with the abilities and stages of child development. Self-reliance given early on is very useful for children who are adapted to the abilities and development of children and will have a positive impact on their adult life. The 
role of parents is very much needed to develop independence in children, fathers and mothers must collaborate to help children grow children's independence.

Family is the earliest place for children to learn to be independent. Family for children is the most comfortable place for children to exercise independence, parents are expected to be able to balance between family and work where parents both father and mother are working outside. Because of the busyness of parents with their careers so that sometimes children stay with their grandmother or caregiver to be able to take care of their children sometimes children are entrusted to child care. The lack of quality meetings between parents and children results in children lacking attention, affection. Resulting in children seeking attention and affection from other people that they do not get from their parents. The attachment between children and parents is very influential on children's behavior so that when children lack attention from their parents they will have different traits or behaviors due to lack of attention from the family. When children feel attached to their parents, children will be afraid to be left behind because they feel when there are parents or closest people the child will feel comfortable and protected Children feel comfortable when they hear the voice of the attached figure (mother), palpation and the presence of the mother.

The flexibility of parents in children will make children more sensitive. When a child has a bad relationship with parents, early childhood is very dependent on his parents. In large cities many families use caregivers to care for and guide their children but sometimes parents do not realize that caregivers only provide services to children rather than guidance, guidance that children do not get early will make children independent. Being an independent child and maintaining child growth is one that parents must achieve in guiding and educating. The independence of the early ones instilled by parents taught from home will make children become independent when at school, children can urinate or defecate into a toilet without being accompanied by a teacher, putting on their own shoes and other small jobs. But in reality independence in children is still experiencing obstacles where parents still do not trust their children that their children can do it themselves, which in fact children can already afford to do it themselves. So that the behavior of children like that without parents knowing it will make children not independent and very dependent on their parents or other people.

The factors that influence independence are parenting, gender and the position of the child's position. The enforcing independence is very dependent on three things: (a) general social attitudes towards independence in culture, (b) parental attitudes and parent-child attachment, (c) peer interaction and support they are against independent behavior. So, independence is influenced by the environment both family and peers. Influence is something or effort that arises to shape the charac- ter, belief or behavior of a person. Parenting (nurturing) is an activity of maintaining, caring for, guiding, educating, training, leading children (Purwanti, 2019). While parenting itself is the effort of parents in caring for children from birth to adolescence to shape the character. Family is the first and foremost educational institution in every aspect of life. Family is the initial phase in forming a generation of quality, independent, resilient, potential, and responsible for the future of national development. The family is a unit that is bound by the existence of interconnectedness or interaction and influences each other between one another. The warmth of parents in the family clearly influences the relationship of the next child when it reaches adulthood. Parents' attention to children from an early age is very decisive towards the development of the child's soul and character in determining his own future (Suriansyah \& Mahriati, 2016).

In social interaction, each individual (personal) in the family will have a process of influencing one another. The process of mutual influence that is carried out consciously from each person and between personalities in the family is usually a process of education (Dewantara, 2016). Relations between individuals in the family will have a major influence on the growth and development of the child's soul as students in the context of education.

The task that must be completed in childhood is independence. Being independent is not something that can be obtained suddenly. Making children more self-sufficient requires a long process that must start early. The key to the success of a child being an independent individual is actually influenced by many factors, one of which is parenting. Therefore, parents play an important role in nurturing, caring for, educating and directing children to be more independent. . "The child's independence is identical to the attitude of being dependent on the people around him".

From the results of observations that have been conducted by researchers, it is known that the independence of children in the Sun Group Kindergarten there are some children who have not shown an independent attitude such as the school bag of children still carried by their parents, releasing shoes is still aided by their parents and there are some children who have not can be far from his mother. This shows that the independence of the child still needs to be trained and needs habituation that can grow self-reliance in one's own child so that they can be responsible. Self-reliance can also be influenced by several factors, namely children are too spoiled or parents still consider children still unable to do it themselves resulting in children are still dependent on their parents or people they consider close. The attitude of parents who have attitudes. As good parents who really want independent children, parents must be more careful in taking care of children, especially during their development. Because every education that parents give to children can have a big influence on their lives in the future. Obeying all 
what the child wants is the wrong way to educate children. Because this action will only make the child become a spoiled child, and he will only rely on parents without trying to get what he wants. Familiarize children to try to do each of their own tasks, and try to get what they want, so they can learn to be responsible, especially for themselves.

A child will feel comfortable and safe when their parents show their love and attention to them, especially when the child needs that form of attention and affection. The care shown by parents in all things can help parents to develop children's independence.

The school atmosphere that feels strange and heavy for children because of the expectations of parents and teachers to be good children, it is necessary to cultivate children's selfconfidence by giving confidence to do something that can be done alone by giving good habits to children according to their age and level of development, for example, throwing trash in its place, serving itself, washing hands, putting toys in its place. Communication is important in explaining independence to children in easy-to-understand language. It is a process carried out by the supervision and guidance of consistent parents and teachers. By teaching discipline to children from an early age, it means that we have trained children to be independent in the future where the key to children's independence is actually in the hands of parents and teachers. The heoretical uses are the results of this study are expected to contribute ideas or add information as well as input knowledge or references that are used as material for the study of academic people in the development of the science of Early Childhood Education regarding social behavior.

Practical Uses for Principals are the results of this study are expected to provide input to school principals, especially TK so that social behavior can be optimized properly during school and build it together with school residents so that the attitude of social behavior can become a habit of children in their neighborhood. The teacher is the result of this study can be used as an illustration of the importance of social behavior to form a noble child personality and to find out the factors that influence social behavior itself to be able to be applied in the child's environment.

Department of Education is this research can construct from the results of research and add references to be able to provide understanding so that solutions can be found for solving problems in the institutions of early childhood education in improving children's social behavior. Becoming a reference for the Education Office to provide more information about parenting programs in Early Childhood Education institutions with parents of children. The next researcher is useful as a reference and the addition of knowledge information in fostering children's social behavior that affects parents' income, parental education and parenting. Thus the next researcher can model the social behavior of children in kindergarten on a family basis.
Based on the formulation of existing problems, the purpose of this study is to test and find out about:

I. The effect of parenting on the position of children in the sun group TK B group, Jekan Raya sub-district, Palangka Raya city.

2. Effect of the position of children in the family on attachment in the sun group TK group B, Jekan Raya sub-district, Palangka Raya city.

3. The influence of the position of children on parents directly on the independence of children in the sun group TK group B, Jekan Raya sub-district, Palangka Raya city.

4. The influence of family attachment directly on the independence of children in the sun cluster TK sub-district of Jekan Raya, Palangka Raya city.

5. The effect of direct parenting on the independence of children in the sun cluster TK in Jekan Raya sub-district, Palangka Raya city.

6. Effect of parenting through indirect attachment to children's independence in TK Gugus Sun, Jekan Raya subdistrict, Palangkaraya city.

7. The influence of children's position through indirect attachment to children's independence in Tk Gugus Matahari, Jekan Raya sub-district, Palangka Raya city.

\section{Methodology}

This type of research uses quantitative descriptive research. The method used in this research is descriptive method with associative (correlational) techniques. Defines associative research as research that aims to find out the relationship between two or more variables. Population is a research subject where individuals are subjected to behavior or can be said as the overall object of research to be studied. The population is parents of children in the Palangka Raya Sun Cluster Kindergarten totaling II8 people. To determine the sample for each school, researchers used the proportional allocation formula. Then the sample of this study amounted to 92 parents of children who attended school in the 7 schools. The instrument of this research was a closed questionnaire using a Likert Scale model made in the form of a check list. Data analysis using multiple linear regression analysis and path analysis.

\section{Result and Discussion}

Based on the results of the research of 92 parents of children who were given the explanation, it can be described as follows from the hypothesis test of influence.

Effect of parenting on family attachment in the Palangka Raya sun group TK B group, Jekan Raya sub-district, Palangka Raya city.

The results of the test of the influence of parenting styles on family attachments in the Palangka Raya sun group TK B group Jekan Raya sub-district, Palangka Raya city can be seen 
from the regression results that Regression test results from the effect of parenting on family attachment in the Palangka Raya sun group TK B group, Jekan Raya sub-district, Palangka Raya city. The results of the significant level are $0.023<0.05$. The results of $\mathrm{r}$ square analysis showed that $0.426=42.9 \%$ gave the effect of parenting parents on family attachment. This can be stated that $\mathrm{Ha}$ is accepted, namely there is the effect of parenting on the family attachment in the Palangka Raya sun group TK B group, Jekan Raya sub-district, Palangka Raya city.

\section{Influence of children's position on family attachment in the} Palangka Raya sun group TK B group, Jekan Raya sub-district, Palangka Raya city.

The results of the study showed that from the position of the child towards family attachment in the TK of the Palangka Raya sun group, group B, the district of Jekan Raya, Palangka Raya, can be seen in the following table:

The influence of the position of the child on family attachment in the sun group TK Palangka Raya group B, Jekan Raya subdistrict, Palangka Raya city. The results of the significant level were $0.048<0.05$. The results of $\mathrm{r}$ square analysis show that $0.504=50.4 \%$ gives the influence of the child's position on family attachment. The results of the study of the hypothesis are known to be Ha accepted, namely there is the influence of the position of the child on family attachment in the sun group TK Palangka Raya group B, Jekan Raya sub-district, Palangka Raya city.

The effect of parenting attitudes towards the independence of children in the Palangka Raya sun group TK B group Jekan Raya sub-district, Palangka Raya city.

Based on the results of the study it is known from the influence of parenting attitudes towards the independence of children in the Palangka Raya sun group TK B group Jekan Raya sub-district Palangka Raya city can be seen in the effect of parenting attitudes towards the independence of children in the Palangka Raya sun group TK B group Jekan Raya sub-district, Palangka Raya city. The results of the significant level are 0.030 $<0.05$. The results of $\mathrm{r}$ square analysis showed that $0.639=$ $63.9 \%$ gave the effect of parenting attitudes towards independence. Ha accepted that there is a positive influence on parenting attitudes towards the independence of children in the sun group TK Palangka Raya group B sub-district Jekan Raya city of Palangka Raya.

Influence of the position of children on the independence of children in the sun group TK Palangka Raya group B, Jekan Raya sub-district, Palangka Raya city.

The results of the study indicate the influence of the position of children on the independence of children in the Palangka Raya sun group TK B group Jekan Raya sub-district, Palangka Raya city. This can be seen in the following the influence of the position of children on the independence of children in the sun group TK Palangka Raya group B, Jekan Raya sub- district, Palangka Raya city. The results of the significant level were $0.02 \mathrm{I}<0.05$. The results of $\mathrm{r}$ square analysis show that $0.639=63.9 \%$ gives the influence of the child's position on independence. Then the results of the hypothesis test indicate that $\mathrm{Ha}$ is accepted, that is, there is an influence of the position of the child on the independence of children in the sun group TK Palangka Raya group B, Jekan Raya sub-district, Palangka Raya city.

Effects of family attachment on the independence of children in the sun group TK Palangka Raya group B, Jekan Raya subdistrict, Palangka Raya city

The results showed that from the influence of family attachment on the independence of children in the Palangka Raya sun group TK B group, Jekan Raya sub-district, Palangka Raya city, The influence of family attachment on the independence of children in the Palangka Raya sun group TK B group Jekan Raya sub-district, Palangka Raya city. The results of the significant level are $0,000<0,05$. The results of $\mathrm{r}$ square analysis show that $0.875=87.5 \%$ gives the effect of family attachment to children's independence. Then it can be seen that the results of the test showed a positive influence on family attachment to the independence of children at the Palangka Raya sun group TK B group, Jekan Raya sub-district, Palangka Raya city.

Effect of parenting through family attachment to the independence of children in the sun group TK Palangka Raya group B, Jekan Raya sub-district, Palangka Raya city

The results of the path analysis test show that the effect of parenting through family attachment to the independence of children in the Palangka Raya sun group TK B group, Jekan Raya sub-district, Palangka Raya city. The results of path analysis show that the results of the level of contribution from the path analysis from the direct relationship of parenting through family attachment to independence with the Standardized beta Coefficients value of 0.247 with parenting through family attachment to children's independence is 0.476 , then the level of relationship can be known the indirect is $0.247 \times 0.928=$ 0.229 , the indirect relationship of positive indirect relationship parenting through family attachment to independence is 0.229 . The results of the sig level of each variable are $0,000<0,05$, this means that $\mathrm{Ha}$ is accepted and Ho is rejected ie there is an indirect relationship between parenting through family attachment to independence in the TK of the Sun Group Palangka Raya group B sub-district Jekan Raya, Palangka Raya city.

Based on the results of the terminated coefficients, the results of the significant level of the $F$ test are $0,000<0,05$. The results of $\mathrm{r}$ square analysis show that $0.875=87.5 \%$ gives the effect of family attachment to children's independence. So based on these results it shows that there are still other variables that have an effect of $100 \%$ by $32.5 \%$ which has an influence on learning independence. 
Influence of the position of the child through family attachment to the independence of children in the sun group TK Palangka Raya group B, Jekan Raya sub-district, Palangka Raya city

The results of the study showed that the position of the child through family attachment to the independence of children in the Palangka Raya sun group TK B group Jekan Raya sub-district, Palangka Raya city.

The influence of the position of the child through family attachment to the independence of the child at the Palangka Raya sun group TK B group Jekan Raya sub-district, Palangka Raya city. The results of the path analysis show that the results of the significant level of the $\mathrm{F}$ test are $0,000<0.05$. The results of the level of contribution from the path analysis from the direct relationship of parenting through family attachment to independence with the Standardized beta Coefficients value of 0.304 with the position of the child through family attachment to the independence of children is 0.929. 0.229, the indirect relationship of a positive indirect relationship to parenting through family attachment to independence is 0.229 . The results of the sig level of each variable are $0,000<0,05$, this means that $\mathrm{Ha}$ is accepted and Ho is rejected, namely there is an indirect relationship between the position of the child through family attachment to the independence of children in the sun group TK Palangka Raya group B sub-district Jekan Raya in Palangka Raya.

Based on the results of the terminated coefficients, it can be seen in the following table:

Table I. Results of Determination coefficient Influence of the position of the child through family attachment to the independence of children in the sun group TK Palangka Raya group B, Jekan Raya sub-district, Palangka Raya city

\begin{tabular}{|l|r|r|r|c|}
\hline Model & \multicolumn{1}{|c|}{ R } & R Square & $\begin{array}{c}\text { Adjusted R } \\
\text { Square }\end{array}$ & $\begin{array}{c}\text { Std. Error of the } \\
\text { Estimate }\end{array}$ \\
\hline $\mathrm{I}$ & $.94 \mathrm{I}^{2}$ & .886 & .883 & \multicolumn{1}{c|}{ I.4I978 } \\
\hline
\end{tabular}

a. Predictors: (Constant), ZI, Y2

The results of $\mathrm{r}$ square analysis show that $0.886=88.6 \%$ gives the influence of the position of the child through family attachment to the independence of the child. The results of the path analysis show that there are other variables that influence the independence of children in the Palangka Raya sun group TK B group, Jekan Raya sub-district, Palangkaraya city. The results showed that the level of influence showed that there were still other variables giving an influence of $100 \%$, there were $11.4 \%$ in addition to the variable position of the child and family attachment.

\section{Conclusion and Recommendation}

The results showed that there was influence:

I. Effect of parenting on family attachment in the sun group TK Palangka Raya group B Jekan Raya sub-district, Palangka Raya city

2. Influence of the position of the child on family attachment in the Palangka Raya sun group TK B group, Jekan Raya sub-district, Palangka Raya city

3. Effect of parenting attitudes on the independence of children in the sun group TK Palangka Raya group B Jekan Raya sub-district, Palangka Raya city

4. Effect of the position of children on the independence of children in the sun group TK Palangka Raya group B subdistrict Jekan Raya city of Palangka Raya

5. Influence of family attachment to the independence of children in the sun group TK Palangka Raya group B, Jekan Raya sub-district, Palangka Raya city

6. Effect of parenting through family attachment to the independence of children in the sun group TK Palangka Raya group B, Jekan Raya sub-district, Palangka Raya city

7. Influence of the position of the child through family attachment to the independence of children in the sun group TK Palangka Raya group B sub-district Jekan Raya city of Palangka Raya

\section{Recommendation}

This research is expected to contribute to science, especially in providing education to children and applying parenting in accordance with the character of children so that there are no problems in shaping the independence of children in understanding all independent behavior. Because the attachment of children will be able to give a big influence on parents in providing education to children.

\section{Acknowledgment}

Research is expected to provide knowledge to future readers and researchers. thank you to the first supervisor and II counselor, Erny Wahdini. Advisor II: Ahmad Suriansyah who has given encouragement to researchers to be able to complete this research on time.

\section{References}

Dewantara, D. (2016), Penerapan Model Pembelajaran Problem Based Learning untuk Meningkatkan Aktivitas dan Hasil Belajar Siswa pada Pelajaran IPA (Studi pada Siswa Kelas V SDN Pengambangan 6 Banjarmasin, Jurnal Paradigma, Volume II, Nomor 2, Juli 2016.

Hasan, Maimunah. (2009). Pendidikan anak usia dini. Jogjakarta: Diva Press. 
Maimunah. (2018). The Integration of Sentra-Based Learning and Involvement of Family Program at Early Childhood in Developing Character Building (Multi Case at Paud Mawaddah and Paud Alam Berbasis Karakter Sayang Ibu Banjarmasin, Indonesia), Volume 5, ISSN: 2501 III I

Noorhafizah dan Dahlina. (2016) Meningkatkan Hasil Belajar IPS pada Materi Perkembangan Teknologi Menggunakan Model Pembelajaran Cooperative Script Kombinasi dengan course Review Horay di Kelas IV SDN Tatah Jaruju Kecamatan Tatah Makmur Kabupaten Banjar, Jurnal Paradigma, Volume II, Nomor 2, Juli 2016.

Novitawati dan Mutiarany. (2016). Upaya Mengembangkan Motorik Halus (Menempel Gambar dengan Tepat) melalui Metode Demonstrasi Dikombinasikan dengan Metode Proyek Menggunakan Teknik Mozaik Bahan Dasar Beras dan Biji-Bijian pada Kelompok B di TK Taruna Banjarmasin, Jurnal Paradigma, Volume II, Nomor 2, Juli 2016.

Purwanti, Ratna. (2019), Introducing Language Aspect (English) to Early Childhood through The Combination of Picture and Picture Model, Talking Stick Model, Flashcard Media, and Movement and Song Method In BI Group at Matahariku Bilingual Kindergarten Landasan Ulin Tengah Banjarbaru, Indonesia, volume 5, European Journal of Education Studies. ISSN: 250I - III I

Rahmawati, E. (2019). Relationship between Emotional Intelligence, Spiritual Intelligence and Teacher Performance through Work Motivation as Intervening Variable in Islamic Elementary School In Banjarmasin, Indonesia. Volume 5, European Journal of Education Studies. ISSN: 250I - III I

Suriansyah, A \& Mahriati, S. (2016). Meningkatkan Hasil Belajar Konsep Sifat-Sifat Bangun Ruang dengan Model Pembelajaran Two Stay Two Stray dan Media Realia Siswa Kelas V SDN Pengambangan 8 Kota Banjarmasin, Jurnal Paradigma, Volume II, Nomor 2, Juli 2016. 